\title{
Impact of Reducing Irritative Symptoms in Non-Muscle Invasive Bladder Cancer During BCG Instillation: A Pilot Study
}

\author{
Kas Invaziv Olmayan Mesane Kanserinde BCG Verilmesi Sırasında \\ Irritatif Semptomların Azaltılmasının Önemi: Bir Pilot Çalışma
}

\author{
Osman Köse $\odot$, Yigit Akın $\oplus$, Hakan Gülmez $\oplus$, Erhan Ateş $\oplus$, Sacit Nuri Görgel $\odot$ \\ Serkan Özcan $\odot$, Bülent Katı $\odot$, Yüksel Yılmaz $\odot$
}

Cite as: Köse O, Akın Y, Gülmez H, et al. Impact of reducing irritative symptoms in non-muscle invasive bladder cancer during BCG instillation: A pilot study. Forbes J Med. 2020;1(3):84-9.

\begin{abstract}
Objective: We evaluated use of anticholinergics, mirabegron, and combination of anticholinergics with mirabegron during Bacillus Calmette-Guérin (BCG) instillation for reducing irritative symptoms in patients with non-muscle invasive bladder cancer (NMIBC).

Method: Prospectively recorded data of NMIBC patients receiving BCG were retrospectively evaluated between August 2015 and April 2019. Patients with low-grade T1 solitary papillary lesions $<4 \mathrm{~cm}$ were included in the study. Validated questionnaires (OAB-V8) for irritative symptoms adapted to Turkish language, and QoL index forms were filled out by the study participants. OAB-V8 scores of $\geq 8$ were considered as an indication to start medical treatment for irritative symptoms. Groups were formed according to daily used anticholinergic drugs and combinations as follows: Group 1, tolterodine; Group 2, solifenacin 5mg; Group 3, mirabegron, and Group 4, mirabegron with solifenacin $5 \mathrm{mg}$.

Results: Mean follow- up period was $20.4 \pm 6.8$ months. There were 132 patients [ 110 men (83\%) and $22(17 \%)$ women] with irritative symptoms and NMIBC. Mean age of the study population was $59.7 \pm 12.4$ years. The OAB-V8 scores and QoL indexes significantly improved with all drugs. However, in subgroup analyses, Group 4 provided the most dramatic improvement in OAB-V8 and QoL index scores ( $\mathrm{P}=0.02$ for both). The longest in time to micturition was recorded in Group $4(\mathrm{P}=0.04)$. Tumour recurrence was similar for groups 12 months after $B C G$ instillation $(P=0.9)$, however the least recurrence was observed in Group 4.

Conclusions: Combination of solifecacin and mirabegron can reduce irritative symptoms, improve QoL, and prolong time to micturition, during BCG instillation in selected NMIBC patients. This combination may also decrease recurrence rates in this patient population.
\end{abstract}

Keywords: Anticholinergic, Bacillus Calmette-Guérin, bladder cancer, irritative symptoms, quality of life

öz

Amac: Kas invaziv olmayan mesane kanseri (KIOMK) hastalarında Bacillus Calmette-Guerin (BCG) uygulaması sırasında irritatif semptomları azaltmak için kullanılan antikolinerjik, mirabegron ve antikolinerjik ile mirabegron kombinasyonunun değerlendirilmesi amaçlandı.

Yöntem: Ağustos 2015 ile Nisan 2019 arasında BCG alan KiOMK hastalarının prospektif olarak kaydedilen verileri retrospektif olarak değerlendirildi. Sadece $4 \mathrm{~cm}$ 'den küçük soliter papiller lezyonu olan düşük dereceli T1 dahil etme kriterleriydi. Dilimize uyarlanmış aşırı aktif mesane versiyon-8 (OAB-V8) formu ve hayat kalite $(\mathrm{QoL})$ indeksi formları irritatif semptomlar için dolduruldu. OAB-V8 skoru $\geq 8$ olması halinde, irritatif semptomlar için tedaviye başlama endikasyonu olarak kabul edildi. Gruplar günlük pratikte kullandıkları antikolinerjik ilaçlara ve kombinasyona göre Grup 1 tolterodin, Grup 2 solifenasin 5 mg, Grup 3 mirabegron ve Grup 4 solifenasin 5 mg mirabegron kullanacak şekilde oluşturuldu.

Bulgular: Ortalama takip süresi $20,4 \pm 6,8$ aydı. İrritatif semptomlar ve KiOMK olan 132 hasta [1 10 erkek (\%83) ve 22 (\%17) kadın] vardı. Ortalama yas 59,7+12,4 yıldı. OAB-V8 skorları ve QoL indeksleri tüm ilaçlarla önemli ölçüde iyileşti. Bununla birlikte, alt grup analizlerinde, Grup 4, $\mathrm{OAB}-\mathrm{V} 8$ ve $\mathrm{Q}$ oL indeks puanlarında en fazla iyileşmeyi sağladı (her ikisi için $\mathrm{P}=0,02$ ). İşeme zamanı en uzun Grup 4'te kaydedildi $(\mathrm{P}=0,04)$. Tümör rekürrensi $\mathrm{BCG}$ uygulamasından 12 ay sonra gruplar için benzerdi $(P=0,9)$, ancak en az nüks Grup 4'teydi.

Sonuç: Solifecacin ve mirabegron'un kombinasyonu, seçilmiş KiOMK hastalarında BCG aşılama sırasında tahriş edici semptomları azaltabilir, QoL geliştirebilir ve işemeye kadar olan süreyi uzatabilir. Bu aynı zamanda bu hasta popülasyonunda nüksü azaltabilir.

Anahtar kelimeler: Antikolinerjik, Bacillus Calmette-Guerin, mesane kanseri, tahriş edici semptomlar, yaşam kalitesi

() Telif hakkı Forbes Tıp Dergisi. Logos Tıp Yayıncilık tarafindan yayınlanmaktadır. Bu dergide yayınlanan bütün makaleler Creative Commons Atıf-GayriTicari 4.0 Uluslararası Lisansı ile lisanslanmıștır.

(C) Copyright Forbes Journal of Medicine. This journal published by Logos Medical Publishing.

Licenced by Creative Commons Attribution-NonCommercial 4.0 International (CC BY-NC 4.0)
Received/Geliș: 04.12.2020

Accepted/Kabul: 09.12.2020

Publication date: 30.12 .2020

Yiğit Akın

İzmir Katip Çelebi Üniversitesi

Tıp Fakültesi Atatürk Eğitim

Araştırma Hastanesi Üroloji Kliniği, İzmir - Türkiye

yigitakin@yahoo.com

ORCID: 0000-0001-7627-3476

O. Köse 0000-0003-4070-6676

S.N. Görgel 0000-0001-7628-1249

S. Özcan 0000-0002-2459-139X

Y. Yılmaz 0000-0002-0548-9322

İzmir Katip Çelebi Üniversitesi Tıp Fakültesi, Üroloji Anabilim Dalı, İzmir, Türkiye

H. Gülmez 0000-0001-5467-3743 Izmir Demokrasi Üniversitesi Tıp Fakültesi, Aile Hekimliği Anabilim Dalı, İzmir, Türkiye

E. Ates 0000-0002-9677-5673

Adnan Menderes Üniversitesi Tıp Fakültesi, Üroloji Anabilim Dalı, İzmir, Türkiye

B. Katı 0000-0002-4024-5147 Harran Üniversitesi Tıp Fakültesi, Üroloji Anabilim Dalı, İmir, Türkiye 


\section{INTRODUCTION}

Intravesical Bacillus Calmette-Guérin (BCG) administration following transurethral resection of moderate and/or high-risk non-muscle invasive bladder cancer (NMIBC) is considered as the most effective treatment to reduce recurrence and progression. ${ }^{1,2}$ Despite its efficacy, side effects of BCG and/or irritative symptoms often limit the patient's ability to tolerate the treatment process. $^{3}$

Local and systemic side effects may cause discontinuation of intravesical BCG therapy in approximately $20 \%$ of the patients. ${ }^{4}$ Storage and irritative symptoms including urgency and pollakiuria were defined as lower urinary tract symptoms (LUTS). Besides, these symptoms usually simulate cystitis-like symptoms and are the most common local side effects of BCG administration. ${ }^{5-7}$ The accepted duration of effective treatment for BCG instillation is 2 hours. $^{7}$ However, NMIBC patients might micturate before completing 2 hours due to storage symptoms as a part of irritative symptoms. ${ }^{8}$

In addition, transurethral resection can indirectly lead to the development of irritative symptoms with/without urge incontinence. By the way, patients could experience more severe local side effects of BCG. ${ }^{9}$ Moreover, low estrogen levels in postmenopausal women and benign prostatic hyperplasia in men can pose risks for the development of irritative symptoms. ${ }^{10,11}$ In this manner, the co-incidence of bladder cancer (BCa) and symptoms of irritative symptoms can increase with advancing age. ${ }^{12}$

Nevertheless, it is supposed that prevention of irritative symptoms during treatment of NMIBC can improve the quality of life (QoL). Other than this, to prevent irritative symptoms might increase oncological efficacy. Anticholinergic drugs, mirabegron and combination of mirabegron with anticholinergics may be used for these aims. According to our best knowledge, there is no study comparing efficiency of different drugs for irritative symptoms in NMIBC patients, in the published literature.
For this purpose, we aimed to compare the efficacy and oncologic outcomes of using anticholinergics, mirabegron, and solifenacin-mirabegron combination in NMIBC patients with irritative symptoms receiving intravesical BCG. Our hypothesis is that solifenacin and mirabegron combination therapy may prevent symptoms better than other medications.

\section{MATERIAL and METHODS}

Prospectively recorded data were retrospectively evaluated regarding irritative symptoms of NMIBC patients between August 2015 and April 2019. This is a non-randomized, multi-centre, and open-labelled study. All patients were informed for the study and signed consent forms were collected. Institutional review board approved the study. Exclusion criteria were presence of multiple tumours in bladder, carcinoma in-situ, high grade $\mathrm{T} 1 \mathrm{BCa}, \geq \mathrm{T} 2 \mathrm{Bca}$, active urinary infection, previous overactive bladder (OAB) syndrome, other cancer and/or previous pelvic radiotherapy due to cancer, previous endoscopic/open/laparoscopic prostate surgery, and irregular followup. Since high grade NMIC patients might need multiple and excessive endoscopic resections, irritative symptoms of them might be more frequent and homogeneous distribution of patients in these groups might be disrupted.

All patients with low-grade T1 NMIBC are asked to complete OAB-V8 forms 13 under the supervision of a doctor in urology outpatient clinic 1 month after transurethral resection of bladder tumour (TUR-BT). When the OAB-V8 scores were higher than 8 , the patient was considered to have significantly severe irritative symptoms. Then, medical treatment was given and again OAB-V8 form was completed in the first week of treatment. Additionally, we asked patients to complete quality of life index (QoL) forms.

All patients were divided into 4 groups according to the use of anticholinergic and combination of solifenacin with mirabegron as follows: Group 1, tolterodine $4 \mathrm{mg}$; Group 2, solifenacin $5 \mathrm{mg}$; Group 3, mirabegron; Group 4, mirabegron with solifenacin $5 \mathrm{mg}$. All drugs were used daily once 
according to the prescription information.

All patients with low-grade T1 NMIBC had undergone BCG $80 \mathrm{mg}$ (TICE $®$ strain) therapy. We used $10 \mathrm{Fr}$ urethral catheter and patients were advised not to micturate up to 2 hours. All patients recorded time to micturition after BCG instillation. Because we would like to create homogeneous groups, patients who were receiving standard treatment were enrolled in the study. Patients, who received BCG maintenance therapy were excluded.

All completed forms and patient's data were recorded on Microsoft $₫$ Excel Sheets. The Statistical package for social sciences (SPSS) for MacOs V.21 was used. Paired t-tests and chisquare tests were used to compare categorical variables. One-way ANOVA was used to determine differences among groups. The level of statistical significance was accepted as $\mathrm{P}<0.05$.

\section{RESULTS}

The mean follow-up was $20.4 \pm 6.8$ months. Mean age of the patients was $59.7 \pm 12.4$ years. There were 132 patients [1 10 men (83\%) and $22(17 \%)$ women] with irritative symptoms and low-grade T1 NMIBCs in total. Group 1 included 38, Group 2, 27, Group 3, 32, and Group 4, 35 patients. The demographic data were summarised in Table 1 according to age and gender. There was no statistical difference among all groups. The OAB-V8

Table 1. Demographic data of the groups.

\begin{tabular}{lccc}
\hline Groups & Female n (\%) & Male n (\%) & P value \\
\hline Group 1 $(\mathrm{n}=38)$ & $6(15.8 \%)$ & $32(84.2 \%)$ & \\
Group 2 $(\mathrm{n}=27)$ & $5(18.5 \%)$ & $22(81.5 \%)$ & 0.9 \\
Group 3 $(\mathrm{n}=32)$ & $6(18.8 \%)$ & $26(81.3 \%)$ & \\
Group 4 $(\mathrm{n}=35)$ & $5(14.3 \%)$ & $30(85.7 \%)$ & \\
\hline
\end{tabular}

scores, time to micturition, and QoL indexes were comparable among the groups before treatment of symptoms (Table 2 ).

The OAB-V8 scores and QoL indexes significantly increased in all groups. However, in subgroup analyses, most statistically significant improvement was found in Group 4 for OAB-V8 and QoL index scores ( $\mathrm{P}=0.02$ for both parameters). Additionally, the longest time to micturition was recorded in Group $4(\mathrm{P}=0.04)$. All these data are shown in Table 2.

According to follow-up after instillation of BCG for 12 months, disease recurrences were seen in patients in Groups $1(n=8), 2(n=5)$, and $3(n=6)$, which were comparable among groups $(\mathrm{P}=0.98)$, (Table 3 ). We offered early radical cystectomy or BCG maintenance therapy for all patients with disease recurrence. All of them wanted to continue BCG. Follow-up period has been continuing.

The most recognized side effect of combination treatment was constipation however; all side effects were well tolerated.

\section{DISCUSSION}

In this study we evaluated the effectiveness of the treatment modalities for irritative symptoms in low grade T1 NMIBC. It is supposed that NMIBC patients can have irritative voiding and storage symptoms as a part of BCa symptom complex. ${ }^{14}$

Table 3. Recurrence rates in groups.

\begin{tabular}{lcc}
\hline Parameters & Recurrence & P value \\
\hline Group 1 $(\mathrm{n}=38)$ & $8(21.1 \%)$ & \\
Group 2 $(\mathrm{n}=27)$ & $5(18.5 \%)$ & 0.9 \\
Group 3 $(\mathrm{n}=32)$ & $6(18.8 \%)$ & \\
Group 4 $(\mathrm{n}=35)$ & $6(17.1 \%)$ & \\
\hline
\end{tabular}

Table 2. Pre-and post-treatment scores of the groups.

\begin{tabular}{lcccccc}
\hline Parameters & $\begin{array}{c}\text { Pre-treatment } \\
\text { Group 1 }\end{array}$ & $\begin{array}{c}\text { Post-treatment } \\
\text { Group 1 }\end{array}$ & $\begin{array}{c}\text { Pre-treatment } \\
\text { Group 2 }\end{array}$ & $\begin{array}{c}\text { Post-treatment } \\
\text { Group 2 }\end{array}$ & $\begin{array}{c}\text { Pre-treatment } \\
\text { Group 3 }\end{array}$ & $\begin{array}{c}\text { Post-treatment } \\
\text { Group 3 }\end{array}$ \\
\hline OAB-V8 scores & $17.5 \pm 5.5$ & $15.5 \pm 5.2$ & $17.4 \pm 4.9$ & $13.7 \pm 4.8$ & $16.7 \pm 4.9$ & $14 \pm 4.1$ \\
QoL & $2.2 \pm 0.8$ & $2.9 \pm 1.2$ & $2.2 \pm 0.8$ & $3.4 \pm 1.3$ & $2 \pm 0.9$ & $3.1 \pm 1.4$ \\
Time to micturition (min.) & $65.1 \pm 16.3$ & $69.6 \pm 15.9$ & $70.6 \pm 16.7$ & $77.4 \pm 15.9$ & $67.3 \pm 12.8$ & $73 \pm 12.1$ \\
\hline
\end{tabular}

Abbreviations: OAB-V8: Overactive bladder-version 8, QoL: Quality of life

*Statistically significant $P$ value. 
Nevertheless, clinicians usually presume those symptoms as natural manifestations in NMIBC patients after TUR-BT. In addition, BCG instillation can aggravate these symptoms. Thus, discomfort of the patients increases. On the other hand, randomized controlled studies showed a 6-week instillation of BCG could prevent the rate of disease recurrence and progression. ${ }^{15,16}$ Thus, firstly we prefer BCG in patients with NMIBC. It is very well known that the BCG instillation itself and catheterization performed in the course of $\mathrm{BCG}$ therapy can increase irritative symptoms. Clinicians usually advise these patients to continue the BCG instillation even they have irritative symptoms and discomfort. ${ }^{17}$ Another problem is to provide optimal treatment with BCG. The direct and indirect causes of irritative symptoms in NMIBC patients is their inability to urinate 2 hours after BCG instillation. In the view of all these, to inquire irritative symptoms, to complete $\mathrm{OAB}-\mathrm{V} 8$ forms, and to initiate treatment of irritative symptoms before BCG treatment seem logical approaches to achieve optimal NMIBC treatment and to avoid recurrences. We could provide these in all groups after treatment of irritative symptoms, however the significant improvement was provided in Group 4. Because we used two different pathways to prevent irritative symptoms with combination of solifenacin and mirabegron. Chung et al. ${ }^{18}$ reported effective decrease in catheter related symptoms using solifenacin before BCG instillation after TUR-BT. We did more and one step further as comparing 4 different groups for preventing irritative symptoms during BCG instillation. Combination treatment provided us better results without any additional side effects. Drake et al. ${ }^{19}$ reported efficacy of mirabegronsolifenacin combination in a multicentre large cohort study. Sideway et al. ${ }^{20}$ commented efficacy of this treatment in the course of developing irritative symptoms. Our results are parallel to these reports. On the other hand, Allison and Gibson reported increased QoL with mirabegron and disappointing results of mirabegronsolifenacin combination. ${ }^{21}$ However, our results were completely different from results of Allison et al. ${ }^{21}$ The combination had better results than mirabegron and solifenacin per se in our study. The possible cause of these discrepancy is that our patients did not have clinical OAB before TUR-BT. We used the similar medical treatment for OAB. However, we just use all anticholinergics, beta3 mimetic, and their combination for irritative symptoms. Nevertheless, we strongly offer clinicians to query irritative symptoms in NMIBC patients. Then, medical treatment of irritative symptoms can reduce symptoms in these patient populations.

Moreover, Group 4 patients could have significantly improved QoL and prolonged time to micturition after treatments. These are clear outcomes of clinical effectiveness of the combination treatment. ${ }^{22}$ We mentioned the possible causes of irritative symptoms in our study population. ${ }^{23}$

Furthermore, mirabegron has similar clinical results with solifenacin per se. ${ }^{24}$ Over and above, to get higher effectiveness without increasing side effects mirabegron was combined with solifenacin. ${ }^{25}$ Improved QoL and prolonged time to micturition were the essential parametres of our study outcomes. Besides, combination was better than other treatment modalities. In this way, when the patients' QoL is increased they can be motivated to continue BCG instillation. Besides, prolonged time to micturition can help clinicians to determine optimum treatment.

However, the recurrence rate was similar among all groups the least recurrence was observed in Group 4. This may be a result of all the above. Either none of the patients gave up medication because of side effects of treatment for irritative symptoms or they continued BCG.

We have some limitations. First of all, we could not create groups using all anticholinergic drugs because of missing data. Second limitation was low number of patients in groups. Thirdly, when the patient could not tolerate BCG some modifications could also be tried as use of low dose BCG or change to mitomycin instillation. In addition, BCG-refractory patients were not included in this study.

In view of all these, we focused on the effectiveness of combination treatment in NMIBC during 
BCG instillation. We found clinical and statistically significant improvement in symptoms of irritative symptoms, QoL, and time to micturition. This is also the first study that showed benefits of mirabegron and solifenacin combination in NMIBC, in published literature. Nonetheless, our results should be confirmed with large population studies to be conducted in near future.

\section{CONCLUSIONS}

Time to micturition is one of the essential criteria during BCG instillation used for the treatment of NMIBC. Clinicians should consider irritative symptoms and QoL in these patient populations. Solifenacin-mirabegron combination can reduce irritative symptoms, improve QoL, and prolong time to micturition during BCG instillation in selected NMIBC patients. However, treatment of irritative symptoms might also provide good results in oncological control which should be confirmed in studies performed with large cohorts of these patient populations.

Ethics Committee Approval: Instutional Review Board approved the study numbered (2018/188).

\section{Conflict of Interest: None.}

Funding: None.

Informed Consent: Informed consent forms were signed by all patients.

\section{REFERENCES}

1. Babjuk M, Böhle A, Burger M, Capoun O, Cohen D, Compérat EM, et al. EAU Guidelines on NonMuscle-invasive Urothelial Carcinoma of the Bladder: Update 2016. Eur Urol. 2017;71:447-61. doi.org/10.1111/1746-8361.12157

2. Brausi M, Witjes JA, Lamm D, Persad R, Palou J, Colombel $M$, et al. A review of current guidelines and best practice recommendations for the management of non muscleinvasive bladder cancer by the International Bladder Cancer Group. J Urol. 2011;186:2158-67. juro.2011.07.076

3. Lamm DL, Blumenstein BA, Crissman JD, Montie JE, Gottesman JE, Lowe BA, et al. Maintenance bacillus Calmette-Guerin immunotherapy for recurrent TA, $\mathrm{T} 1$ and carcinoma in situ translational cell carcinoma of the bladder: a randomized Southwest Oncology Group study. J Urol. 2000;163:1124-9. doi.org/10.1016/S0022-5347(05)67707-5

4. Lamm DL, van der Meijden PM, Morales A, Brosman SA, Catalona WJ, Herr HW, et al. Incidence and treatment of complications of bacillus CalmetteGuerin intravesical therapy in superficial bladder cancer. JUrol. 1992;147:596-600. doi.org/10.1016/ S0022-5347(17)37316-0

5. Koya MP, Simon MA, Soloway MS. Complications of intravesical therapy for urothelial cancer of the bladder. J Urol. 2006;175:2004-10. doi. org/10.1016/S0022-5347(06)00264-3

6. Koga H, Kuroda M, Kudo S, Yamaguchi A, Usami $M$, Suzuki T, et al. Adverse drug reactions of intravesical bacillus Calmette-Guerin instillation and risk factors of the development of adverse drug reactions in superficial cancer and carcinoma in situ of the bladder. Int J Urol. 2005;12:145-51. doi. org/10.1111/j.1442-2042.2005.01000.x

7. Saint F, Irani J, Patard JJ, Salomon L, Hoznek A, Zammattio S, et al. Tolerability of bacille CalmetteGue' rin maintenance therapy for superficial bladder cancer. Urology. 2001;57:883-8. doi. org/10.1016/S0090-4295(00)01117-1

8. Thrasher JB, Crawford ED. Complications of intravesical chemotherapy. Urol Clin North Am. 1992;19:529-39.

9. Abrams P, Andersson KE, Birder L, Brubaker L, Cardozo L, Chapple C, et al. Members of Committees; Fourth International Consultation on Incontinence. Fourth International Consultation on Incontinence Recommendations of the International Scientific Committee: evaluation and treatment of urinary incontinence, pelvic organ prolapse, and fecal incontinence. Neurourol Urodyn. 2010;29:21340. doi.org/10.1002/nau.20870

10. Robinson D, Cardozo L, Milsom I, Pons ME, Kirby $M$, Koelbl H, et al. Oestrogens and overactive bladder. Neurourol Urodyn. 2014;33:1086-91. doi. org/10.1002/nau.22464

11. Sexton CC, Coyne KS, Thompson C, Bavendam T, Chen CI, Markland A. Prevalence and effect on health-related quality of life of overactive bladder in older americans: results from the epidemiology of lower urinary tract symptoms study. J Am Geriatr Soc. 2011;59:1465-70. doi. org/10.1111/j.1532-5415.2011.03492.x

12. Kiriluk KJ, Prasad SM, Patel AR, Steinberg GD, Smith ND. Bladder cancer risk from occupational and environmental exposures. Urol Oncol. 2012;30:199-211. doi.org/10.1016/j. urolonc.2011.10.010

13. Acquado C, Kopp Z, Coyne KS, Corcos J, Tubaro A, Choo MS, et al. Translating overactive bladder questionnaires in 14 languages. Urology. 2006;67:536-40. doi.org/10.1016/j. urology.2005.09.035

14. Song YS, Cho KH, Kim KW, Yoon JH, Doo SH, Yang WJ, et al. A Case of Bladder Cancer Found during a Workup for Urge Incontinence. Int Neurourol J. 2010;14:130-2. inj.2010.14.2.130

15. Böhle A, Bock PR. Intravesical bacille calmetteguérin versus mi-tomycin $c$ in superficial bladder cancer: formal meta-analysis of comparative studies on tumor progression. Urology. 2004;63:682-6. https://doi.org/10.1016/j.urology.2003.11.049

16. Han RF, Pan JG. Can intravesical bacillus Calmette- 
Guérin reduce recurrence in patients with superficial bladder cancer? A meta- analysis of randomized trials. Urology. 2006;67:1216-23. doi. org/10.1016/j.urology.2005.12.014

17. Woldu SL, Bagrodia A, Lotan Y. Guideline of guidelines: non-muscle-invasive bladder cancer. BJU Int. 2017;119:371-80. doi.org/10.1111/bju.13760

18. Chung JM, Ha HK, Kim DH, Joo J, Kim S, Sohn DW, et al. Evaluation of the Efficacy of Solifenacin for Preventing Catheter-Related Bladder Discomfort After Transurethral Resection of Bladder Tumors in Patients With Non-Muscle Invasive Bladder Cancer: A Prospective, Randomized, Multicenter Study. Clin Genitourin Cancer. 2017;15:157-62. doi. org/10.1016/j.clgc.2016.05.006

19. Drake MJ, Chapple C, Esen AA, Athanasiou S, Cambronero J, Mitcheson D, et al. BESIDE study investigators. Efficacy and Safety of Mirabegron Add-on Therapy to Solifenacin in Incontinent Overactive Bladder Patients with an Inadequate Response to Initial 4-Week Solifenacin Monotherapy: A Randomised Double-blind Multicentre Phase 3B Study (BESIDE). Eur Urol. 2016;70:136-45. doi. org/10.1016/j.eururo.2016.02.030

20. Sidaway P. Incontinence: Adding mirabegron to solifenacin improves patient outcomes. Nat Rev Urol. 2016;13:298-9. doi.org/10.1038/ nrurol.2016.86

21. Allison SJ, Gibson W. Mirabegron, alone and in combination, in the treatment of overactive bladder: real-world evidence and experience. Ther Adv
Urol. 2018;10:411-9. doi. org/10.1177/1756287218801282

22. Herschorn S, Chapple CR, Abrams P, Arlandis S, Mitcheson D, Lee KS, et al. Efficacy and safety of combinations of mirabegron and solifenacin compared with monotherapy and placebo in patients with overactive bladder (SYNERGY study). BJU Int. 2017;120:562-75. doi.org/10.1111/bju.13882

23. Peyronnet B, Mironska E, Chapple C, Cardozo L, Oelke M, Dmochowski R, et al. A Comprehensive Review of Overactive Bladder Pathophysiology: On the Way to Tailored Treatment. Eur Urol. 2019;75:988-1000. doi.org/10.1016/j. eururo.2019.02.038

24. Abrams P, Kelleher C, Staskin D, Kay R, Martan A, Mincik I, et al. Combination treatment with mirabegron and solifenacin in patients with overactive bladder: exploratory responder analyses of efficacy and evaluation of patient-reported outcomes from a randomized, double-blind, factorial, dose-ranging, Phase II study (SYMPHONY). World J Urol. 2017;35:827-38. doi.org/10.1007/s00345-0161908-1

25. Mueller ER, van Maanen R, Chapple C, Abrams P, Herschorn S, Robinson D, et al. Long-term treatment of older patients with overactive bladder using a combination of mirabegron and solifenacin: a prespecified analysis from the randomized, phase III SYNERGY II study. Neurourol Urodyn. 2019;38:779-92. doi.org/10.1002/nau.23919 